\title{
Seabream ghrelin: cDNA cloning, genomic organization and promoter studies
}

\author{
Chung-Man Yeung ${ }^{1}$, Chi-Bun Chan ${ }^{1}$, Norman Y S Woo ${ }^{2}$ \\ and Christopher $\mathbf{H}$ K Cheng ${ }^{1}$
}

Departments of ${ }^{1}$ Biochemistry and ${ }^{2}$ Biology, The Chinese University of Hong Kong, Shatin, N.T., Hong Kong, China

(Requests for offprints should be addressed to C H K Cheng; Email: chkcheng@cuhk.edu.hk)

\begin{abstract}
Recent studies have indicated that ghrelin stimulates growth hormone release from the pituitary via the growth hormone secretagogue receptor (GHSR). We have previously isolated two GHSR subtypes from the pituitary of the black seabream Acanthopagrus schlegeli. In the present study, we have cloned and characterized ghrelin from the same fish species at both the cDNA and gene levels. The full-length seabream ghrelin cDNA, isolated from seabream stomach using a novel approach by exploiting a single conserved region in the coding region, was found to encode a prepropeptide of 107 amino acids, with the predicted mature ghrelin peptide consisting of 20 amino acids (GSSFLSPSQKPQNR GKSSRV). Embedded in this full-length cDNA is a putative fish orthologue of the recently reported mammalian obestatin peptide. The ghrelin gene in black seabream, obtained by genomic PCR, was found to encompass four exons and three introns, possessing the same structural organization as in tilapia and goldfish, but different from that in rainbow trout. In addition, a 2230-bp 5'-flanking region of the seabream ghrelin gene was obtained by genome walking. Sequence analysis revealed that, as in the case of the human ghrelin gene, there is neither a GC box nor a CAAT box present in the isolated 5 '-flanking region. However, a number of putative transcription factorbinding sites different from the human counterpart were found in the $5^{\prime}$-flanking region of the seabream ghrelin gene, suggesting that different cis- and trans-acting
\end{abstract}

elements are involved in controlling their gene expression. Functional activity of this $5^{\prime}$-flanking region was examined by cloning it into the pGL3-Basic vector upstream of the luciferase reporter gene and transfected into various cell lines. Positive promoter activity could only be recorded in the colon-derived Caco-2 cells, suggesting that the cloned $5^{\prime}$-flanking region represents the functional promoter of the seabream ghrelin gene, which exhibits tissue-specific promoter activity. Using reverse transcriptase PCR analysis, expression of ghrelin was detected only in the seabream stomach, but not in the other tissues examined, including the brain, gill, intestine, kidney, liver and spleen. This stomach-specific expression of ghrelin in seabream is subject to regulation, as administration of growth hormone or ipamorelin to the fish in vivo was demonstrated to enhance its expression. Reminiscent of the homologous upregulation found in the transcriptional control of the seabream GHSR gene, a similar homologous regulatory mechanism might also exist in controlling the expression of seabream ghrelin. The identification of both GHSR and ghrelin from a single fish species would facilitate our subsequent studies on the elucidation of the physiological functions of the ghrelin/GHSR system in teleost. The possible existence of obestatin in teleost opens up new research avenues on the somatotropic axis in fish.

Journal of Endocrinology (2006) 189, 365-379

\section{Introduction}

Ghrelin, the endogenous ligand for growth hormone (GH) secretagogue receptor (GHSR), is involved in regulating diverse physiological functions in vertebrates, in addition to the stimulation of GH secretion (Gualillo et al. 2003). The cDNA encoding ghrelin was first isolated from mammalian stomach (Kojima et al. 1999) and subsequently from other non-mammalian species including bullfrog (Kaiya et al. 2001), chicken (Kaiya et al. 2002), goldfish (Unniappan et al. 2002), eel (Kaiya et al. 2003b), tilapia (Kaiya et al. 2003c, Parhar et al. 2003), and rainbow trout (Kaiya et al. 2003a). Ghrelin possesses a unique structure in which the third serine residue is modified by an acylation that is essential for its biological activity (Kojima et al. 1999).

Previous studies on the isolation of ghrelin from fish species have indicated that the function of ghrelin in stimulating GH release from the pituitary appears to be conserved from fish to mammals (Kojima et al. 1999, 
Table 1 Sequences of the primers used

\begin{tabular}{|c|c|c|}
\hline \multirow[b]{2}{*}{ Primer name } & Sequence $\left(5^{\prime}\right.$ to $\left.3^{\prime}\right)$ & Purpose \\
\hline & & \\
\hline FGD & GGCWCCAGCTTYYTNWSNCC & 3'-RACE \\
\hline GTD & GGYWCCAGCTTCYTSAGC & $3^{\prime}-\mathrm{RACE}$ \\
\hline oligo-dT & CCGAATTCTCGAGATCGA $(\mathrm{T})_{18}$ & 3'-RACE \\
\hline SGR1 & GTCССТСТGСТGССТСТGTG & Library PCR \\
\hline SGR2 & ACGCTGAATGATCTCCTGCAGC & Library PCR \\
\hline M13-R & AGCGGATAACAATTTCACACAGG & Library PCR \\
\hline SGFL-F & CACATGTGGGTCATATTGTTAGC & Libaray PCR and RT-PCF \\
\hline SGFL-R & GTTTATCAATGCTTTATTTATATGGAC & Library PCR and RT-PCR \\
\hline SGW-P & GCACCACAAAGTCAGAGAACAG & Genome walking \\
\hline SGW-N & TGGTGTATTAAAGATGTAAGATGC & Genome walking \\
\hline SGW-4 & CGAAGAAGTCGGTCACAGAAG & Genome walking \\
\hline SGW-5 & GCAACACAGATTATGCCGTAG & Genome walking \\
\hline AP1 & GTAATACGACTCACTATAGGGC & Genome walking \\
\hline AP2 & ACTATAGGGCACGCGTGGT & Genome walking \\
\hline Actin-F & ACCCAGATCATGTTCGAGACC & RT-PCR \\
\hline Actin-R & ATGAGGTAGTCTGTGAGGTCG & RT-PCR \\
\hline SBG-PRO-F1 & AGGССТСTTCATAGССТССТC & Promoter cloning \\
\hline SBG-PRO-F2 & CTCGGTACCCCTTGTGTGCGAGTGTTTCT & Promoter cloning \\
\hline SBG-PRO-F3 & CTCGGTACCTTTGCTCATAGAGTTTGGCC & Promoter cloning \\
\hline SBG-PRO-F4 & CTCGGTACCTATCAAGGGTGTTCTGСTCC & Promoter cloning \\
\hline SBG-PRO-R1 & TCTTACATCTTTAATACACCA & Promoter cloning \\
\hline
\end{tabular}

Kaiya et al. 2003b, 2003c). Moreover, it has been demonstrated that ghrelin is capable of stimulating food intake in goldfish (Unniappan et al. 2002). These findings indicate that a ghrelin/GHSR system is also operative in fish. However, the cognate GHSR has not been cloned and characterized from those fish species in which their ghrelins have been isolated or studied. To date, fish GHSR has only been reported in two species, the pufferfish Spheroides nephelus (Palyha et al. 2000) and the black seabream Acanthopagrus schlegeli (Chan \& Cheng 2004), and is functionally characterized in black seabream only (Chan \& Cheng 2004, Chan et al. 2004b). The putative ghrelin gene present in pufferfish, however, has not yet been isolated. We have recently identified and characterized two full-length GHSR cDNAs from the pituitary of the black seabream and demonstrated that these two receptor transcripts are derived from alternative splicing of a single GHSR gene (Chan \& Cheng 2004). Herein we report the cloning and characterization of the ghrelin gene from the same fish species. Moreover, we have further demonstrated homologous upregulation of ghrelin expression in the seabream stomach. This work represents the first study on a teleost in which both the GHSR and ghrelin genes have been cloned.

\section{Materials and Methods}

\section{Cloning of seabream ghrelin $\mathrm{cDNA}$}

Initial attempts to clone the seabream ghrelin cDNA failed because of the difficulty in designing effective primer pairs for reverse transcriptase (RT)-PCR owing to the small size of the peptide. A different approach was subsequently adopted and this involved the design of two overlapping forward degenerate primers from a single conserved region of ghrelin. A cDNA fragment towards the $3^{\prime}$-end of seabream ghrelin was obtained using these primers together with an oligo-dT primer in a $3^{\prime}$-rapid amplification of cDNA ends (RACE) approach. Subsequently, gene-specific reverse primers were designed from this partial sequence, allowing us to obtain the rest of the ghrelin cDNA using a library PCR approach. The experimental details are described below. Total RNA was first prepared from seabream stomach using TriPure Isolation Reagent (Roche Applied Science). First-strand cDNA was then made from $4 \mu \mathrm{g}$ total RNA in the reverse transcription reaction. The reaction was carried out at $42{ }^{\circ} \mathrm{C}$ for $50 \mathrm{~min}$ using Superscript II RT (Invitrogen). Based on previously published fish ghrelin sequences (Unniappan et al. 2002, Kaiya et al. 2003c, Parhar et al. 2003), two degenerate primers, FGD and GTD (see Table 1 for their primer sequences), were designed and employed together with an oligo-dT primer in the first-round and nested PCR, respectively.

The PCR conditions were as follows: $5 \mathrm{~min}$ at $94{ }^{\circ} \mathrm{C}$ for initial denaturation, followed by 36 cycles of $1 \mathrm{~min}$ at $94{ }^{\circ} \mathrm{C}$ (denaturation), $1 \mathrm{~min}$ at $55^{\circ} \mathrm{C}$ (annealing), and $1 \mathrm{~min}$ at $72{ }^{\circ} \mathrm{C}$ (extension), and then $7 \mathrm{~min}$ at $72{ }^{\circ} \mathrm{C}$ for the final extension. A dominant PCR product (with a size of about $800 \mathrm{bp}$ ) was obtained from the nested PCR. Cloning and sequencing of the PCR product revealed that it shared a high sequence homology with the tilapia 
ghrelin cDNA. Subsequently, two gene-specific primers, SGR1 and SGR2 (see Table 1), were designed from the partial cDNA sequence and employed to amplify from a seabream stomach cDNA library constructed in the pCMV.SPORT6 vector (Invitrogen) in order to obtain the $5^{\prime}$-end sequence of the ghrelin cDNA. SGR1 and SGR2 were used together with the primer M13-R in the first round and nested PCR, respectively. The PCR conditions were the same as described above except that the annealing temperature was at $56{ }^{\circ} \mathrm{C}$. The nested PCR yielded a distinct product with a size of about $400 \mathrm{bp}$, which was subsequently cloned and sequenced. Finally, a pair of gene-specific primers, SGFL-F and SGFL-R (see Table 1), were designed and used to amplify the fulllength ghrelin sequence from the seabream stomach cDNA library. This final confirmation step was essential to demonstrate that the composite sequence obtained from the two separate fragments truly represents the actual full-length ghrelin sequence. Also, the nucleotide sequence of each PCR product obtained above was confirmed by the sequencing of at least five independent clones in each case.

\section{Determination of the structural organization of the seabream ghrelin gene}

Genomic DNA was extracted from seabream liver as previously described (Chan \& Cheng 2004). Briefly, frozen seabream liver was homogenized in lysis buffer $(10 \mathrm{mM}$ Tris/HCl, $\mathrm{pH} 8.0,50 \mathrm{mM}$ EDTA and $0.5 \%$ SDS), followed by proteinase $\mathrm{K}$ digestion. The genomic DNA was then purified by phenol/chloroform extraction and ethanol precipitation. The gene-specific primers SGFL-F and SGFL-R were used to amplify the entire ghrelin gene in the genomic PCR. The PCR conditions were as follows: 5 min at $94^{\circ} \mathrm{C}$ for initial denaturation, followed by 36 cycles of $1 \mathrm{~min}$ at $94{ }^{\circ} \mathrm{C}$ (denaturation), $1 \mathrm{~min}$ at $55^{\circ} \mathrm{C}$ (annealing), and $2 \mathrm{~min}$ at $72{ }^{\circ} \mathrm{C}$ (extension), and then $7 \mathrm{~min}$ at $72^{\circ} \mathrm{C}$ for the final extension. The PCR product was cloned and sequenced from both strands. The complete genomic sequence was obtained and confirmed by sequencing of at least five independent clones.

Isolation of the $5^{\prime}$-flanking region of the seabream ghrelin gene by genome walking

The $5^{\prime}$-flanking region of the ghrelin gene was isolated using the Universal GenomeWalker Kit (BD Biosciences Clontech, Palo Alto, CA, USA). Five GenomeWalker libraries (independently generated by cutting with the following restriction enzymes: DraI, EcoRV, PvuII, ScaI, and StuI) were constructed according to the manufacturer's instructions. First-round PCR was carried out using the adaptor primer 1 (AP1) and the gene-specific primer SGW-P (used in the first genome-walking experiment) or SGW-4 (used in the second genome-walking experiment; see Table 1). The PCR conditions were as follows: $3 \mathrm{~min}$ at $94{ }^{\circ} \mathrm{C}$ for initial denaturation, followed by 38 cycles of 30 s at $94{ }^{\circ} \mathrm{C}$ (denaturation), 30 s at $62^{\circ} \mathrm{C}$ (annealing), and $3 \mathrm{~min}$ at $72{ }^{\circ} \mathrm{C}$ (extension) for 38 cycles, and then $7 \mathrm{~min}$ at $72{ }^{\circ} \mathrm{C}$ for final extension. Nested PCR was performed using the adaptor primer 2 (AP2) and the gene-specific primer SGW-N (used in the first genome-walking experiment) or SGW-5 (used in the second genome-walking experiment; see Table 1) under the same conditions except that the number of cycles was reduced to 35 . The nucleotide sequences of the PCR products obtained above were confirmed by sequencing of at least five independent clones in each case.

\section{Construction of reporter gene plasmids}

The $5^{\prime}$-flanking region of the seabream ghrelin gene was amplified by PCR using SBG-PRO-F1 and SBGPRO-R1 as primers and 700 ng seabream genomic DNA as the template. Subsequent to its sequence determination, the amplicon of the PCR was then cloned into the promoterless pGL3-Basic vector (Promega) to generate the construct $\mathrm{p}(-2230 /+1)$. Another reporter construct $(\mathrm{p}(+1 /-2230))$ containing the same $5^{\prime}$-flanking region as $\mathrm{p}(-2230 /+1)$ but in the reverse direction was made in parallel. Deletion constructs with successive removal of the $5^{\prime}$-region were generated by PCR using the primers SBG-PRO-F2, SBG-PRO-F3, SBG-PRO-F4 and SBGPRO-R1 (Table 1) to generate the constructs $\mathrm{p}(-1614 /$ $+1), \mathrm{p}(-1422 /+1)$, and $\mathrm{p}(-1289 /+1)$. Reporter constructs $\mathrm{p}(-894 /+1)$ and $\mathrm{p}(-450 /+1)$ were made by digesting the $5^{\prime}$-flanking region amplified from SBGPRO-F1 and SBG-PRO-R1 with SacI and NheI respectively. All plasmid DNA preparations were isolated using the QIAprep Spin Miniprep Kit (Qiagen).

\section{Cell culture, transfection and promoter assay}

Cell culture materials were purchased from Invitrogen unless otherwise stated. Cell lines were purchased from ATCC (Manassas, VA, USA; NIH-3T3, HepG2, HEK293, Caco-2) and RIKEN Bioresource Center (Ibaraki, Japan; ECC10, GAKS). NIH-3T3, HepG2, and HEK293 cells were maintained at $37^{\circ} \mathrm{C}$ in Dulbecco's modified Eagle's medium (DMEM) containing 10\% fetal bovine serum (FBS). Caco-2 cells were kept in DMEM at $37^{\circ} \mathrm{C}$ containing non-essential amino acids and 10\% FBS. GAKS cells were maintained at $37^{\circ} \mathrm{C}$ in DMEM containing 5\% FBS. ECC10 cells were maintained in RPMI containing $10 \% \mathrm{FBS}$ at $37^{\circ} \mathrm{C}$. All media were supplemented with antibiotics $(10 \mathrm{U} / \mathrm{ml}$ penicillin and $100 \mu \mathrm{g} / \mathrm{ml}$ streptomycin).

In the transfection experiments, Lipofectamine reagent (Invitrogen) was used as recommended by the manufacturer. Twenty hours before transfection, $1.5 \times 10^{5}$ cells/well were seeded onto $24-w e l l$ tissue-culture plates. 
Five hundred ng seabream ghrelin promoter-reporter constructs and $50 \mathrm{ng}$ pRL-CMV (for normalization of transfection efficiency) containing Renilla luciferase reporter gene were co-transfected into the cells in $250 \mu \mathrm{l}$ serum-free medium. After $5 \mathrm{~h}$ of transfection, the reaction mixture was replaced with 20\% FBS and the cells were incubated for $24 \mathrm{~h}$. The firefly luciferase activities driven by various seabream ghrelin promoter regions were assayed using the Dual-Luciferase Assay System (Promega).

Analysis of ghrelin gene expression in seabream tissues by $R T-P C R$

First-strand cDNA was prepared from various tissues as described above. The gene-specific primers SGFL-F and SGFL-R were used in the RT-PCR to amplify the full-length ghrelin transcript. The PCR conditions were as follows: $5 \mathrm{~min}$ at $94{ }^{\circ} \mathrm{C}$ for initial denaturation, followed by 36 cycles of $1 \mathrm{~min}$ at $94^{\circ} \mathrm{C}$ (denaturation), $1 \mathrm{~min}$ at $55^{\circ} \mathrm{C}$ (annealing), and $1 \mathrm{~min}$ at $72{ }^{\circ} \mathrm{C}$ (extension), and then $7 \mathrm{~min}$ at $72{ }^{\circ} \mathrm{C}$ for the final extension. Mock RT controls were performed to exclude the possibility of genomic DNA contamination in the RNA preparations. Moreover, PCR using a pair of $\beta$-actin primers, Actin-F and Actin-R (see Table 1), was also performed in parallel to indicate the quality of the cDNA templates synthesized. The PCR conditions were as follows: 5 min at $94^{\circ} \mathrm{C}$ for initial denaturation, followed by 26 cycles of $30 \mathrm{~s}$ at $94^{\circ} \mathrm{C}$ (denaturation), $30 \mathrm{~s}$ at $58^{\circ} \mathrm{C}$ (annealing), and $30 \mathrm{~s}$ at $72{ }^{\circ} \mathrm{C}$ (extension), and then $7 \mathrm{~min}$ at $72{ }^{\circ} \mathrm{C}$ for the final extension.

\section{Regulation of ghrelin expression in seabream stomach in vivo}

Black seabream (body length, $24.3 \pm 0.5 \mathrm{~cm}$; body weight, $311.5 \pm 21.7 \mathrm{~g}$ ) of mixed sex purchased from a local marine fish farm were kept in fully aerated seawater at ambient temperature and fed ad libitum once daily with commercial diet. Fishes were injected with either synthetic ipamorelin (NeoMPS, Strasbourg, France) or recombinant seabream GH (GroPep, Thebarton, Australia) intraperitoneally once daily for 4 days. Physiological saline was injected in parallel as the control group. The fishes were then killed by decapitation and their stomachs removed and frozen in liquid nitrogen. The tissue was kept at $-70{ }^{\circ} \mathrm{C}$ until further analysis.

RT-PCR was carried out to assess the expression of ghrelin in seabream stomach as described above. The number of cycles used in each case was determined first by a validation test in which the PCR was performed as described but terminated at different cycle numbers. A kinetic profile of the amount of PCR product generated at different cycle numbers was constructed and the cycle number to be adopted for the gene-expression assessment was chosen within the linear portion of the amplification curve. This validation step is essential to ensure that the amount of the PCR product reflects the amount of template in the original sample. The PCR products were then resolved on an 1.5\% agarose gel and stained with ethidium bromide. The intensity of the amplicon was determined by densitometric scanning using Multi-Analyst software (Bio-Rad).

\section{Statistical analyses}

Where applicable data were analysed by one-way analysis of variance followed by Tukey's test using PRISM software (GraphPad Software, San Diego, CA, USA). Differences were considered statistically significant when $P<0 \cdot 05$.

\section{Results}

\section{Cloning of seabream ghrelin cDNA}

Using degenerate primers (FGD and GTD) designed from the most conserved region of ghrelins (i.e. the core region of the mature peptide, $\mathrm{G}(\mathrm{S} / \mathrm{T}) \mathrm{SFLSP})$ together with an oligo-dT primer, a partial seabream ghrelin cDNA of about $800 \mathrm{bp}$ was obtained in a $3^{\prime}$-RACE approach. Subsequently, two gene-specific reverse primers (SGR1 and SGR2) were designed and employed to isolate the 5 -end sequence from a stomach cDNA library by a library PCR approach. Finally, the full-length ghrelin cDNA (Fig. 1) was amplified from the same library using two specific primers (SGFL-F and SGFL-R) designed at both ends of the full-length sequence. The complete cDNA was found to encode 107 amino acids, with $56 \mathrm{bp}$ in the $5^{\prime}$-untranslated region (UTR) and $564 \mathrm{bp}$ in the $3^{\prime}-$ UTR. Amino acid sequence comparison of the seabream ghrelin with other vertebrate ghrelins (Fig. 2) indicates that it shares the highest homology with the tilapia ghrelin (Fig. 3).

The nucleotide sequences of the ghrelin cDNA and gene reported in this paper have been submitted to the GenBank database under the accession nos. AY643808 and AY643809, respectively.

\section{Structural organization of the seabream ghrelin gene}

The structural organization of the seabream ghrelin gene was determined by genomic PCR using the two genespecific primers SGFL-F and SGFL-R. Sequence analysis of the amplified product (Fig. 4A) revealed that the ghrelin gene in black seabream consists of four exons and three introns (Fig. 4B). The DNA sequences of the exon/intron junctions are shown in Table 2. The exon/intron junctions were found to conform to the GT/AG rule (Chabot 1996). Exon 1 (170 bp) encodes the 5'-UTR and 38 amino acids (including the first 12 amino acids of the 


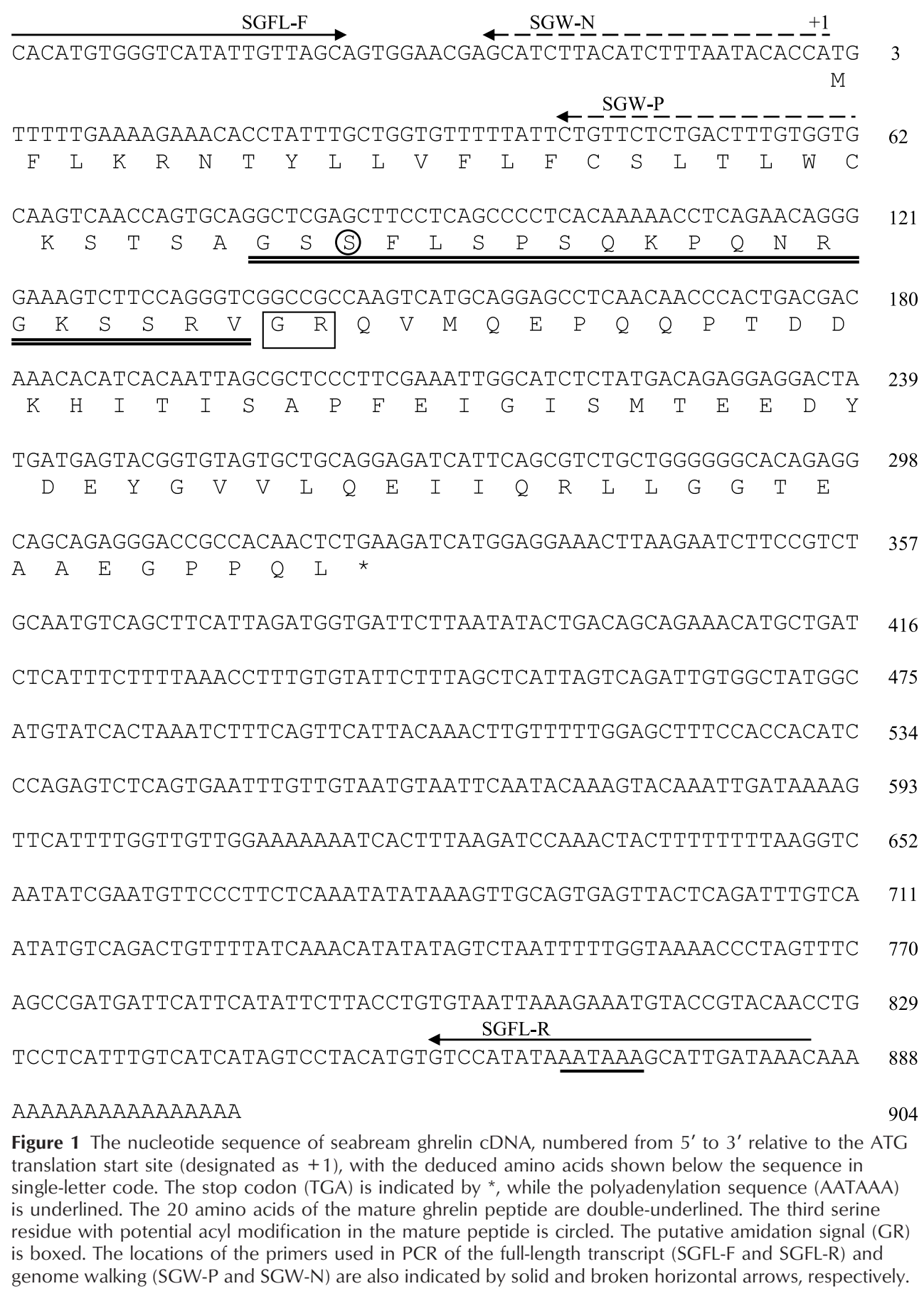

mature ghrelin peptide). Exon 2 (78 bp) is the smallest exon that encodes 26 amino acids (including the remaining eight amino acids of the mature ghrelin peptide). Exon 3 (112 bp) encodes 37 amino acids (including the putative obestatin peptide) and exon 4 (581 bp) encodes the last six amino acids and the $3^{\prime}-\mathrm{UTR}$.
Isolation of the $5^{\prime}$-flanking region of the seabream ghrelin gene

As a first step towards understanding the transcriptional regulation of the seabream ghrelin gene, the $5^{\prime}$-flanking region of the gene was also isolated in the present study. In the first genome-walking experiment, the longest 


Seabream
Tilapia
Eel
Rainbow trout
Goldfish
Bullfrog
Chicken
Turkey
Emu
Human
Rhesus monkey
Mouse
Rat
Dog
Pig
Cow

Seabream
Tilapia
Eel
Rainbow trout
Goldfish
Bullfrog
Chicken
Turkey
Emu
Human
Rhesus monkey
Mouse
Rat
Dog
Pig
Cow

Seabream
Tilapia
Eel
Rainbow trout
Goldfish
Bullfrog
Chicken
Turkey
Emu
Human
Rhesus monkey
Mouse
Rat
Dog
Pig
Cow

\begin{tabular}{|c|c|c|c|c|c|}
\hline & & & & & \\
\hline FLKRNTYLL & VFLFCSLTLW & & GSSF & LSPSQ-K--P & Q----NRGK \\
\hline NTCLL & AFLLCSLTLW & & & LSPSQ-K--P & $Q^{----N K V K}$ \\
\hline RAYI & ILLVCVLALW & & & LSPSQ $-\mathrm{R}--\mathrm{P}$ & QGK-DKK-- \\
\hline TGLM & ILMLCTLALW & AKS & & $K--P$ & QV \\
\hline & FVLI & & & $--P$ & \\
\hline & VVI & & & KIA & \\
\hline & ILL & & & NIQ & \\
\hline G & ILLI & & & $N I Q$ & \\
\hline LLV & ILLE & & & KIQ & \\
\hline VCS & LLL & $-\mathrm{DI}$ & & QRVQ & $Q R$ \\
\hline & LLLLGMLWL- & -DLAM & & $\mathrm{EH}-\mathrm{QRAQ}$ & $Q R$ \\
\hline TICS & LLLLS & -DMAM & & $\mathrm{BH}-\mathrm{QKAQ}$ & $Q R$ \\
\hline & LLLI & $-\mathrm{DM}$ & & LSP & \\
\hline & 至 & 年 & & LSPEH-QKLQ & \\
\hline ח חדת & LLLLS & ADLAN & & LSPEH-QKVQ & QRK-ESKK \\
\hline PWII & ¿LSVLCI & -DL & & LSPEH-QKLQ & -RK-EAK \\
\hline
\end{tabular}

$\begin{array}{llll}60 & 70 & 80 & 90\end{array}$

SRVGRQV--- -----MQEP QQPTDDKHIT ISAPFEIGIS MTEEDYDEYG SRIGRQA--- - - ---MEEP NQANEDKTIT LSAPEEIGVT LRAEDLADYI PRVGRRDSDG ILDLF-MRPP LQDEDIRHIT FNTPFEIGIT MTEELFQQYG PRVGRRDIES FAELF--EGP LHQED-KHNT IKAPFEMGIT MSEEEFQEYG PRMGRRDVAE ------PEI PVIKEDDQFM MSAPFELSVS LSEAEYEKYG GNMNTRGVED DLAGEE---- --------- IGVTFPLDMK MTQEQFQKQR ARLHRRGTES FWDTDET-EG EDDNNSVDIK FNVPEEIGVK ITEREYQEYG ARLHPRGTES FWDTDET-AG EDDNNSVDIK FNVPFEIGVK ITEREYQEYG TKLHRRGVEG FSDTDEA-WA EDDNNSIEIK FNVPFEIGVK ITEEQYQEYG AKLQPRALAG WLRPEDGGQA EGAEDELEVR FNAPFDVGIK LSGVQYQQHS AKLQPRALGG WLRPEDGDQA EGAEDELEIQ FNAPFDVGIK LSGVQYQQHS AKLQPRALEG WLHPEDRGQA EETEEELEIR FNAPFDVGIK LSGAQYQQHG AKLQPRALEG WLHPEDRGQA EEAEEELEIR FNAPFDVGIK LSGAQYQQHG AKLQPRALEG SLGPEDTSQV EEAEDELEIR FNAPFDVGIK LSGPQYHQHG AKLKPRALEG WLGPEDSGEV EGTEDKLEIR FNAPCDVGIK LSGAQSDQHG GRLKPRTLEG QFDPEVGSQA EGAEDELEIR FNAPFNIGIK LAGAQSLQHG

$\begin{array}{rrr}110 & 120 & 130 \\ \text { VVLQEIIQRL } & \text { LGG------ } & \text { TEAAEGPPQL } \\ \text { VELQEIVQRL } & \text { LGN------- } & \text { TETAERPSPR } \\ \text { EVMQKIMQDL } & \text { LMD------- } & \text { TPAKE----- } \\ \text { AVLQKILQDV } & \text { LGD------- TATAE----- } \\ \text { PVLQKVLVNL } & \text { LGD------- } & \text { S-----PLEF } \\ \text { AAVQDFLYSS } & \text { LLSLGSVQDT } & \text { EDKNENPQSQ } \\ \text { QALEKMLQDI } & \text { LAE------- } & \text {-NAEETQTKS } \\ \text { QALEKMLQDI } & \text { FEE------- } & \text {-NAKETQTKD } \\ \text { QMLEKVLGDI } & \text { LEE------- } & \text { NTKETRMKN } \\ \text { QALGKFLQDI } & \text { LWE------- } & \text { EAKEAPADK } \\ \text { QALGKFLQDI } & \text { LWE------- } & \text { EAKEAPADK } \\ \text { RALGKFLQDI } & \text { LWE------- } & \text { EVKEAPADK } \\ \text { RALGKFLQDI } & \text { LWE------- } & \text { EVKEAPANK } \\ \text { QALGKFLQEV } & \text { LWE------- } & \text { DTNEALADE } \\ \text { QPLGKFLQDI } & \text { LWE------- } & \text {-EVTEAPADK } \\ \text { QTLGKFLQDI } & \text { LWE------- } & \text { EAEETLANE }\end{array}$

Figure 2 Protein sequence alignment of the seabream ghrelin with other vertebrate ghrelins. The region corresponding to the mature ghrelin peptide is boxed. The region corresponding to the obestatin peptide in mammals is indicated by a thick black line underneath the aligned sequences. The alignment was generated using the DNASIS program (Hitachi Software Engineering Co., Yokohama, Japan). The amino acid sequences shown were obtained from the NCBI GenBank database (accession numbers: seabream, AY643808; tilapia, AB077764; eel, AB062427; rainbow trout, AB096919; goldfish, AF454389; bullfrog, AB058510; chicken, AB075215; turkey, AY497549; emu, AY338467; human, AB029434; rhesus monkey, AY372274; mouse, AB060078; rat, AB029433; dog, AJ298295; pig, AF308930; cow, AF350329). 


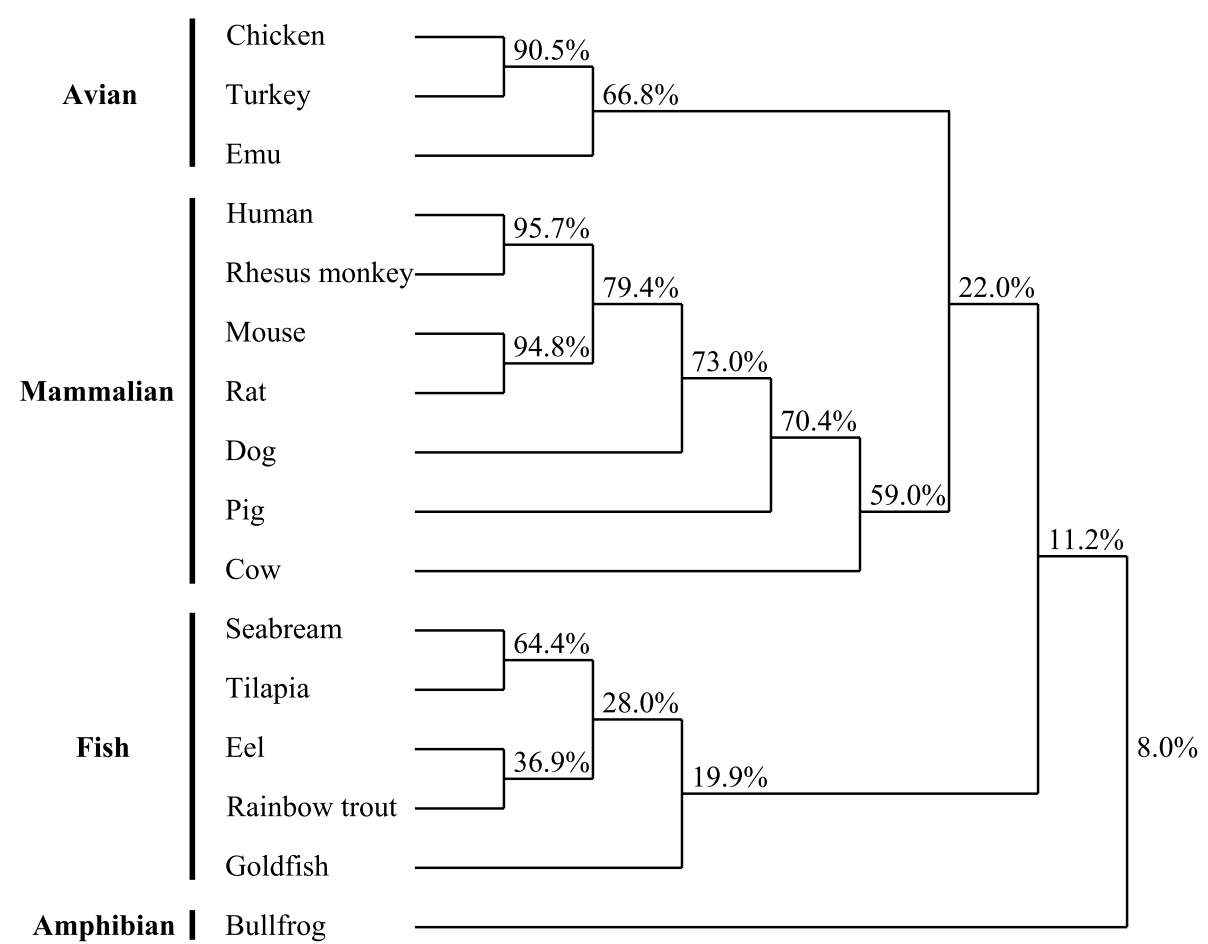

Figure 3 A phylogenetic tree generated from protein sequence alignment of the vertebrate ghrelins using the DNASIS program. The tree was created based on amino acid conservation over time between the different species using the default settings of the program.

PCR product $(\sim 800 \mathrm{bp})$ was obtained from the PvuII GenomeWalker library. In order to isolate a longer $5^{\prime}$-flanking region for transcriptional analysis, a second genome walking was performed using the two genespecific primers SGW-4 (for first-round PCR) and SGW-5 (for nested PCR). Distinct PCR products of sizes of about $1500 \mathrm{bp}$ were obtained from both the StuI and EcoRV GenomeWalker libraries. The PCR products from the StuI library were subsequently cloned and sequenced. From the two consecutive and overlapping genome walks, a 2230-bp 5'-flanking region of the seabream ghrelin gene was finally isolated. Sequence analysis using TFSEARCH software (http://molsun1.cbrc.aist.go.jp/research/db/ TFSEARCH.html) revealed a number of putative transcription factor-binding sites on the $5^{\prime}$-flanking region of the seabream ghrelin gene (Fig. 5).

\section{Functional mapping of the seabream ghrelin promoter}

The promoter activity of the $5^{\prime}$-flanking region of the seabream ghrelin gene was then tested by transfecting the plasmid $\mathrm{p}(-2230 /+1)$ into various cell lines and measuring the putative promoter-driven luciferase activity. A 6-fold increase of luciferase activity over and above the promoter-less control (pGL3-Basic) was recorded in the colon epithelial Caco-2 cells (Fig. 6A). This result suggested that the cloned $5^{\prime}$-flanking region represents the functional promoter of the seabream ghrelin gene. Moreover, this promoter activity was orientation-dependent as no detectable luciferase activity could be measured in Caco-2 cells transfected with the construct $\mathrm{p}(+1 /-2230)$, which has an identical nucleotide sequence to $\mathrm{p}(-2230 /+1)$ but in a reverse orientation. Furthermore, the seabream ghrelin promoter is cell-typespecific as no promoter activity could be detected in the other cell lines originated from embryo fibroblast (NIH3T3), liver (HepG2), kidney (HEK-293) and stomach (ECC10), nor from fish scale fibroblast (GAKS; Fig. 6B).

To further characterize the seabream ghrelin promoter, progressive $5^{\prime}$-deletion mutants were constructed and their activities were assessed in transfected Caco-2 cells. A significant reduction $(P<0 \cdot 001)$ in promoter activity was observed in the construct $p(-1422 /+1)$. Promoter activity was completely abolished when construct $\mathrm{p}(-894 /+1)$ was used and further deletion also gave no measurable luciferase activity. These results suggested that the core promoter region of the seabream ghrelin gene lies within the region -1289 to -894 and an enhancer element may be present within the region -1614 and -1422 . 
A
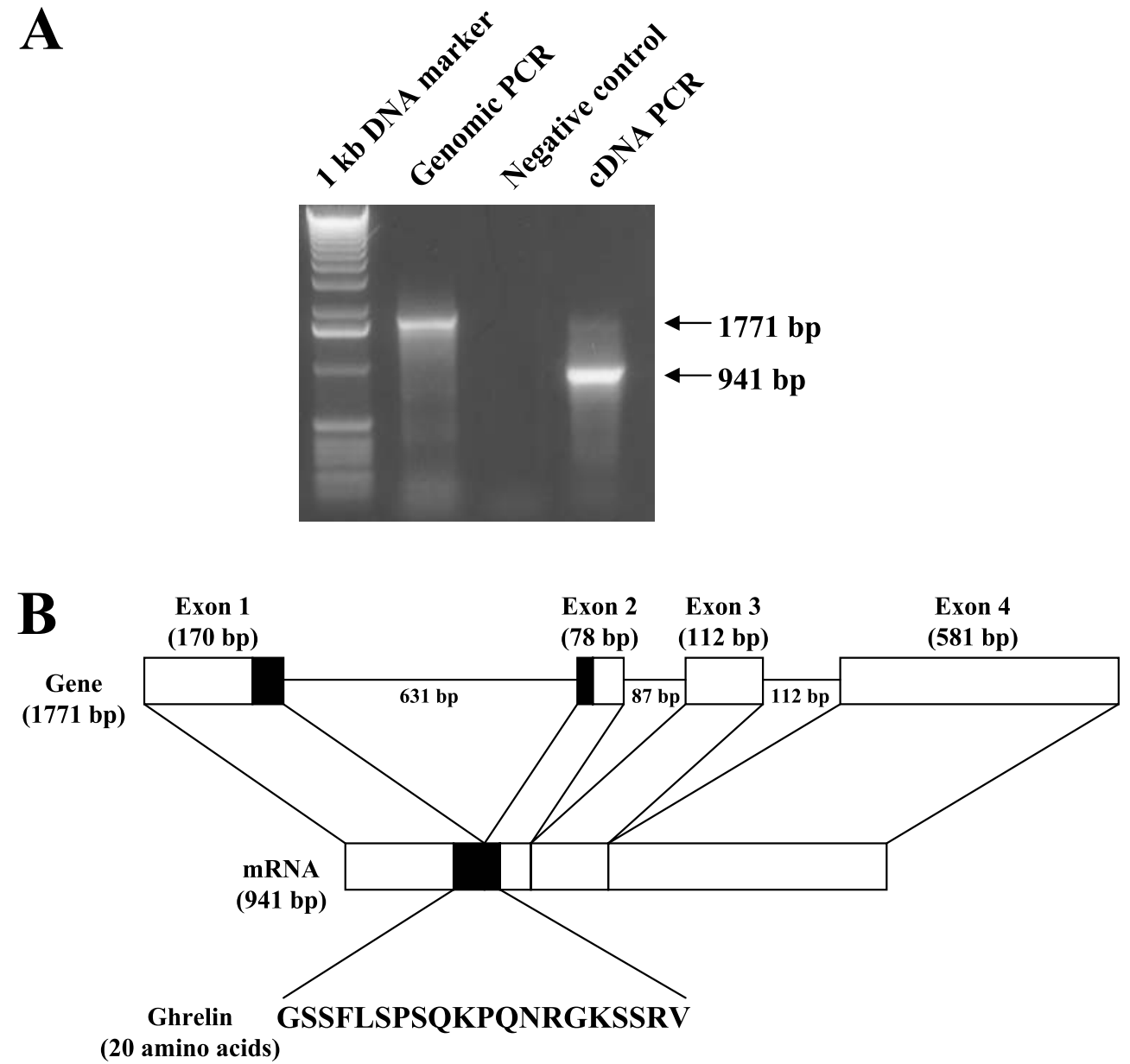

Figure 4 Structural organization of the seabream ghrelin gene. (A) An agarose gel showing the result of the genomic PCR (with the product size of $1771 \mathrm{bp}$ ) using the primers SGFL-F and SGFL-R. Full-length ghrelin transcript $(941 \mathrm{bp})$ was also amplified from a stomach cDNA library using the same primers. (B) A

schematic diagram showing the genomic organization of the seabream ghrelin gene. Exons and introns are represented by boxes and lines, respectively. The region encoding the 20 amino acids of the ghrelin mature peptide is shown in black. The sizes of the exons and introns are also indicated.

Analysis of ghrelin gene expression in seabream tissues by $R T-P C R$

The expression of the ghrelin gene in various seabream tissues was analyzed by RT-PCR using a pair of genespecific primers (SGFL-F and SGFL-R) that amplified the full-length transcript (941 bp). Using this pair of primers, which span three introns of the seabream ghrelin gene, we could only obtain a single distinct band of about $950 \mathrm{bp}$ on the gel, indicating that there was no genomic DNA present in the first-strand cDNA samples since any such contamination would give rise to a much larger amplicon

Table 2 DNA sequences of exon/intron junctions of the seabream ghrelin gene

\begin{tabular}{|c|c|c|c|}
\hline & $5^{\prime}$ splice sequence & Intron size (bp) & $3^{\prime}$ splice sequence \\
\hline \multicolumn{4}{|l|}{ Intron } \\
\hline 1 & AAAACCTCAGgtaagagct & 631 & ttctctgtagAACAGGGGAA \\
\hline 2 & ACACATCACAgtgagtggaa & 87 & ctctaagcagATTAGCGCTC \\
\hline 3 & GAGGCAGCAGgttcgccaaa & 112 & cacctccagAGGGACCGCC \\
\hline
\end{tabular}

Intron sequences are shown in lower case. The conserved GT and AG nucleotides of the introns are underlined. 
AGGCCTCTTCATAGCCTCCTCTTCCTCCATCTCCCACTCCTGCCTCTGAAGCTCCCGCCGCATGTCCTCTGAGAGTA

ACGTCTTGTCAGCTGAGACTTTTCTACACAGTAAAGTCATATCAAAAACAGTTCAAGTTCCCAACATGATCCCAATA AP-4

TCCAGTCTCCAACTTCATAACCTGTAGTAGAATATTTACCCTTTTCCTTTAAGGTCTTGGTCCATTTTCTTAAAATC

TGGCAGGTCTTTCTTCATGCATTTTCGAGATCGGCCCAAAGCGTCAACATAGTCCACCCTACCGACAAACAACGTGA GATA-1

AGGAGAAGAGTTAACAATGAAAGGGTTTCAAACTGTAGAGCATCATCACATATACATTTTGAATTATTTTTTTTCAT Oct-1

TTGTACTGTTTTCATTTATAACTTGCATTCTTAAGATTAGAAGCGGTGGTGGGAGTAGTCCTAGTGATTTGTTCATT

TGTACAGATATTGTATATACAATTTAACAACACACTACTTTAGCTATATTTTTCTTAACTGTTGATAAAGAATGAAT GATA-1 c-Myb AP-1

CAGACGTTACCATTCCTCATCTGGGTTTTGCGGAGGGGGGATAGGAGATGAGCTGTCTCTTTCTTCATCATCTCTAT GATA-2

CCTTGTGTGCGAGTGTTTCTCTCTTTTTGTCAATAATCTTCTGGGTGAAGTCAACCAGGAACAGTCCTTCTGTCTCT CREB

TCATCTGACAAATTACAAGACAAGTTTATTACAAACTAAACATACTCTGTCATACAACAAAATATCAGAGAGGTGTC

ATTTAGGCTTCACCCACCTGGAAAGTCTCCTTTTGTCATTTGCTCATAGAGTTTGGCCTTCTCCTCCAACCTGCGTC

TGTTATAGGCAGATAAATGAGGAGTCAGAGGTTGTGATCACCATTTTTATTATGACAGTAAATCTGCTGTATGATGT GATA-1 AP-1

GTTGAACTGACTTTGCTGTATCAAGGGTGTTCTGCTCCTCAGCCAGCTGCTCTGCATCTTTCTCAGCTCTTGCTGAG c-Myb

AP-4

AP-4

ACACCAGCATTTTGTTTGCTCCAAACATTAGGTTTCTACACCAGAGCACGCAGACAGGACACAGTTAGTGATCTAAA

TGTGCTGTCATACAAGCAGGTCTAAATATCTCTCTAAATGACACAAACTGTACCTTGACTTTCTGATGAGATTTTGA

TGTGAACCCAGCACCAGAGTTTTCTCGCCCAAGTTTATCCTGTTTGAACTGTTCCTGCTTTCTGTAAAGTTCAGCTT

TAAGGTCCACTAGCTGTAACAAAGAAGGCATTATCGACACATAAATCAACAGCGAACTGTTTATATTTATTCTTTAG

CTACTAAAACAACTTTAACTGTGTTTGCTAGCATTTAACGTTATAGCCTGACAGCAGGTTAGCTAACGTTAGCTGTT

CRE-BP

AP-4

CRE-BP

ATAATCATTGAATTAAACGTCCCGAAGCCAAACAGAACATCAGTAAAATGGTTGTACAGCTGTTTTTGTAATGTAAC Oct-1

C/EBPb

TCACCGATGAAGCAGTCACATCAAAGGGTTTCTTCTTTTTTTCCATGCTTACTGGTTATTTTTCTACGGCATAATCT

GTGTTGCTACTTCTGTGACCGACTTCTTCGTTGGTGGCGCAGCTCTCGCGAGAAAACCTGTCGCTTTACCGCCGACT AP-4

AGTGGCGTTTGTTAGTCCAGCTCTGTTTAGATACACTTGTCCTCTGATTACAAAAAATAAGTAAAACTTCAAGGCCT

C/EBPa

GTTGAAAGGTTTTACCACATAAAACCAAAATGTATTGGTGTGGATTTTGTCAAATTCTCCAGATAAGACTCATTTCA

GATA-1

AAAAGAGCTCTATTGTGTTAAGCATTGTTATCGTCAAATATCAACCTTAGTATTTGACATTGCACTATTCCTGGGTA

C/EBP

TATTAACTCAACACTGGTATGCTGCTGGAGAGACATACATGCATAACAGGCTGAATTAGTTCCCATTATCAGTGTCT

CTATGACAGCAATACTATTACCTGCATGACTTTCATTACCACATTGAACAGATAAGATGATCAGCAGGTTGAAACAG

GATA-1

AGAAATGCCTACTTTGTTATCAACTTAAACATTTGAACAGTCCAACGCAAACAAGATATGACAGCACAAGCACCCAT

TATTATTATACTGGATGCATTTTTAAACCAAAATGAAAGCGAATGGAAGCTATATATAGGTATGAACCGGTCAGAAG

CTGAACTCAGGTTGGTGTCACATGTGGGTCATATTGTTAGCAGTGGAACGAGCATCTTACATCTTTAATACACCA

Figure 5 The complete nucleotide sequence of the $5^{\prime}$-flanking region of the seabream ghrelin gene. The numbering of the sequence shown on the right is relative to the ATG translation start site (designated as +1 ). Putative transcription factor binding sites identified in the $5^{\prime}$-flanking region are underlined and labeled.

$-2077$

$-2000$

$-1461$

$-1153$

$-999$

$-922$

$-845$

$-768$

$-691$

$-614$

$-537$

$-460$

$-383$

$-306$

$-229$

$-152$

$-75$ $+1$

$-2154$

$-1923$

$-1846$

$-1769$

$-1692$

$-1615$

$-1538$

$-1384$

$-1307$

$-1230$

$-1076$

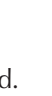



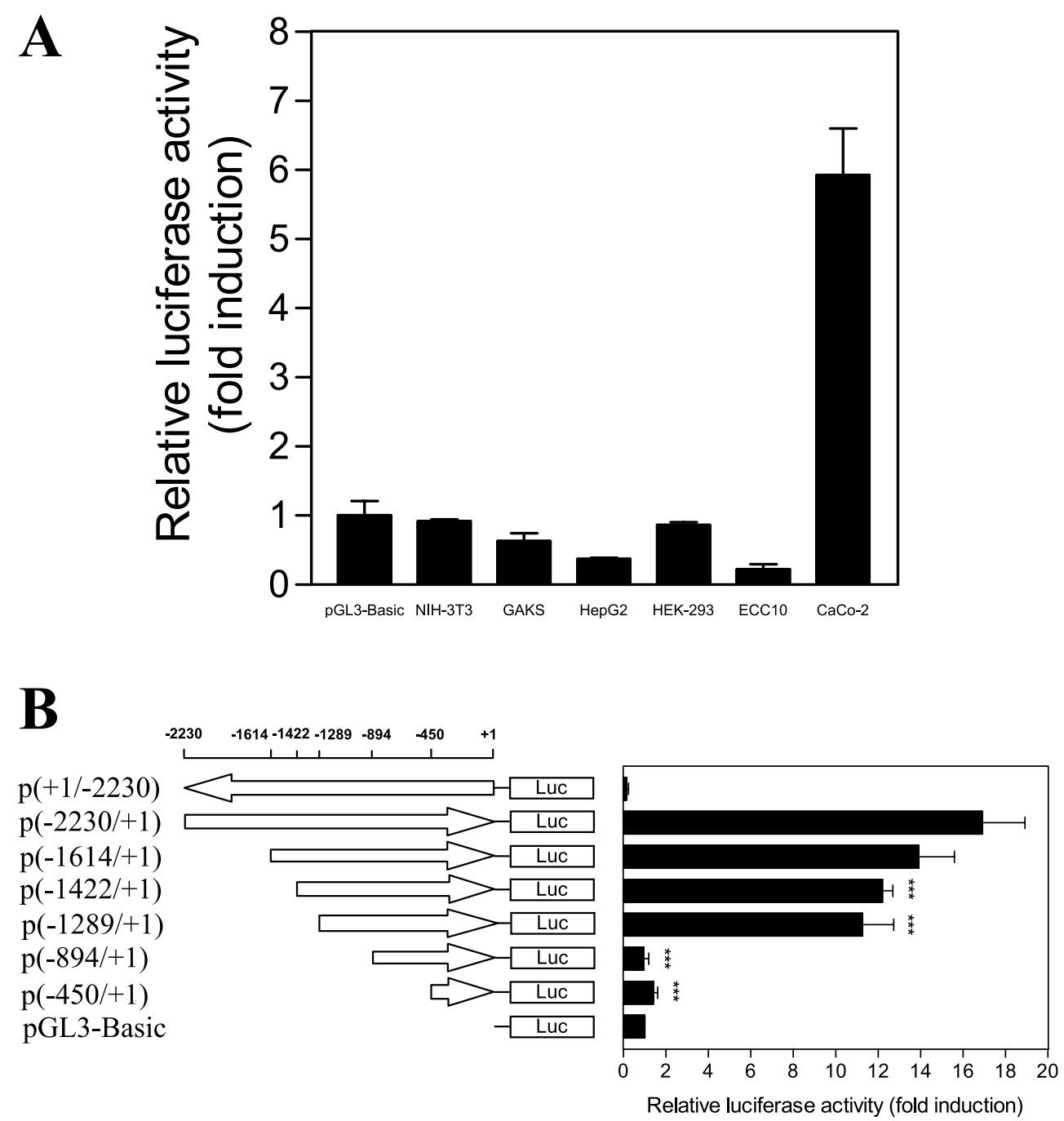

Figure 6 Functional analysis of seabream ghrelin gene promoter. The $5^{\prime}$-flanking region of the seabream ghrelin gene was cloned into the pGL3-Basic vector to generate plasmid $p(-2230 /+1)$ and transfected into various cell lines (A). The putative promoter-driven luciferase activity was assayed using the Dual Luciferase Assay System. Further analysis of the functional region in the seabream ghrelin promoter was performed by transfecting luciferase reporter-plasmids carrying successive $5^{\prime}$-deletion of the seabream ghrelin promoter into Caco- 2 cells (B). Results are expressed as means \pm S.E.M. $(n=9)$. ${ }^{* *} P<0 \cdot 001$ compared with $\mathrm{p}(-2230 /+1)$.

tissues examined (Fig. 7), indicating that the absence of a ghrelin transcript in most tissues could not be attributed to the quality of the cDNA templates.

\section{Regulation of seabream ghrelin expression in stomach}

Hormonal regulation of ghrelin expression in seabream stomach was also studied in vivo. As shown in Fig. 8, ghrelin expression could be enhanced in fish injected with recombinant seabream GH or with the synthetic GH secretagogue ipamorelin in a dose-dependent manner. A significant increase $(P<0 \cdot 05)$ in ghrelin expression was observed when $1 \mu \mathrm{g} / \mathrm{g}$ seabream GH or $100 \mathrm{ng} / \mathrm{g}$ ipamorelin were administered to the fish.

\section{Discussion}

The ghrelin cDNA has been isolated from a number of fish, yet the cognate GHSR has not been cloned from these species. We have previously identified and functionally characterized two GHSR subtypes from the pituitary of a teleost fish, the black seabream Acanthopagrus schlegeli (Chan \& Cheng 2004). In the present study, as part of our 

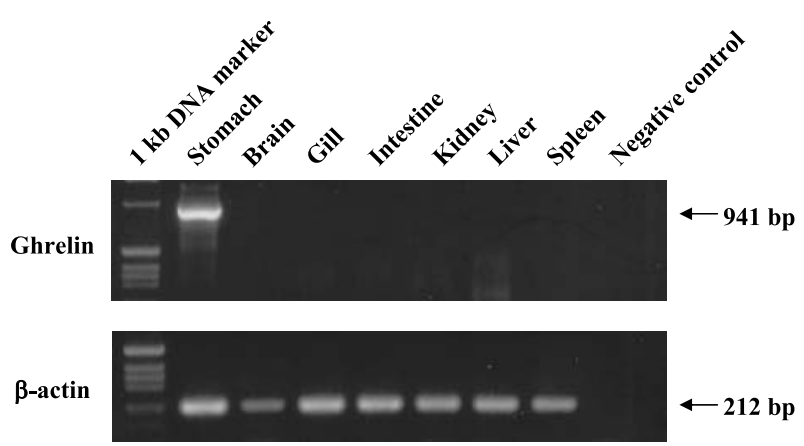

Figure 7 Assessment of ghrelin gene expression in seabream tissues by RT-PCR. The full-length ghrelin transcript (941 bp) was amplified using the primers SGFL-F and SGFL-R and analyzed on an agarose gel. An internal control PCR (with the expected product size of $212 \mathrm{bp}$ ) using two $\beta$-actin primers was also performed.

ongoing work on the elucidation of the physiological functions of the fish ghrelin/GHSR system, we have cloned and characterized the ghrelin from the same fish species at both the cDNA and gene levels.

Initial attempts to design degenerate primers from known ghrelin sequences had encountered difficulties because there is only a single conserved region within the short sequence where primers could be reasonably designed. Thus the conventional method of RT-PCR using a pair of degenerate primers failed. Alternatively we have adopted a novel method in the present study. This entails the design and deployment of two overlapping forward degenerate primers from the single conserved region to obtain a cDNA fragment of the target by a nested 3'-RACE approach. This has successfully generated a cDNA fragment from which gene-specific reverse primers could be designed to enable the successful cloning of the $5^{\prime}$-end sequence using a library PCR approach in a nested manner. This method, which we have successfully employed in obtaining the full-length seabream ghrelin cDNA in the present study, could be equally applicable to other target genes where the design of degenerate primers is severely restricted by the limited conserved regions among the known sequences.

The seabream ghrelin cDNA encodes a total of 107 amino acids, with the predicted mature peptide consisting of 20 amino acids (Fig. 1). Protein sequence alignment of different vertebrate ghrelins (Fig. 2) reveals that the seabream ghrelin shares the highest homology with the tilapia counterpart, as indicated by the phylogenetic tree shown in Fig. 3. This finding of a close evolutionary relationship between seabream and tilapia is in agreement with phylogenetic analysis of other fish hormones such as the type II form of gonadotropin-releasing hormone (Ikemoto \& Park 2003). In fact, a similar evolutionary relationship among teleost species is observed in the present and other studies (Zhu et al. 1999, Nilsson et al.
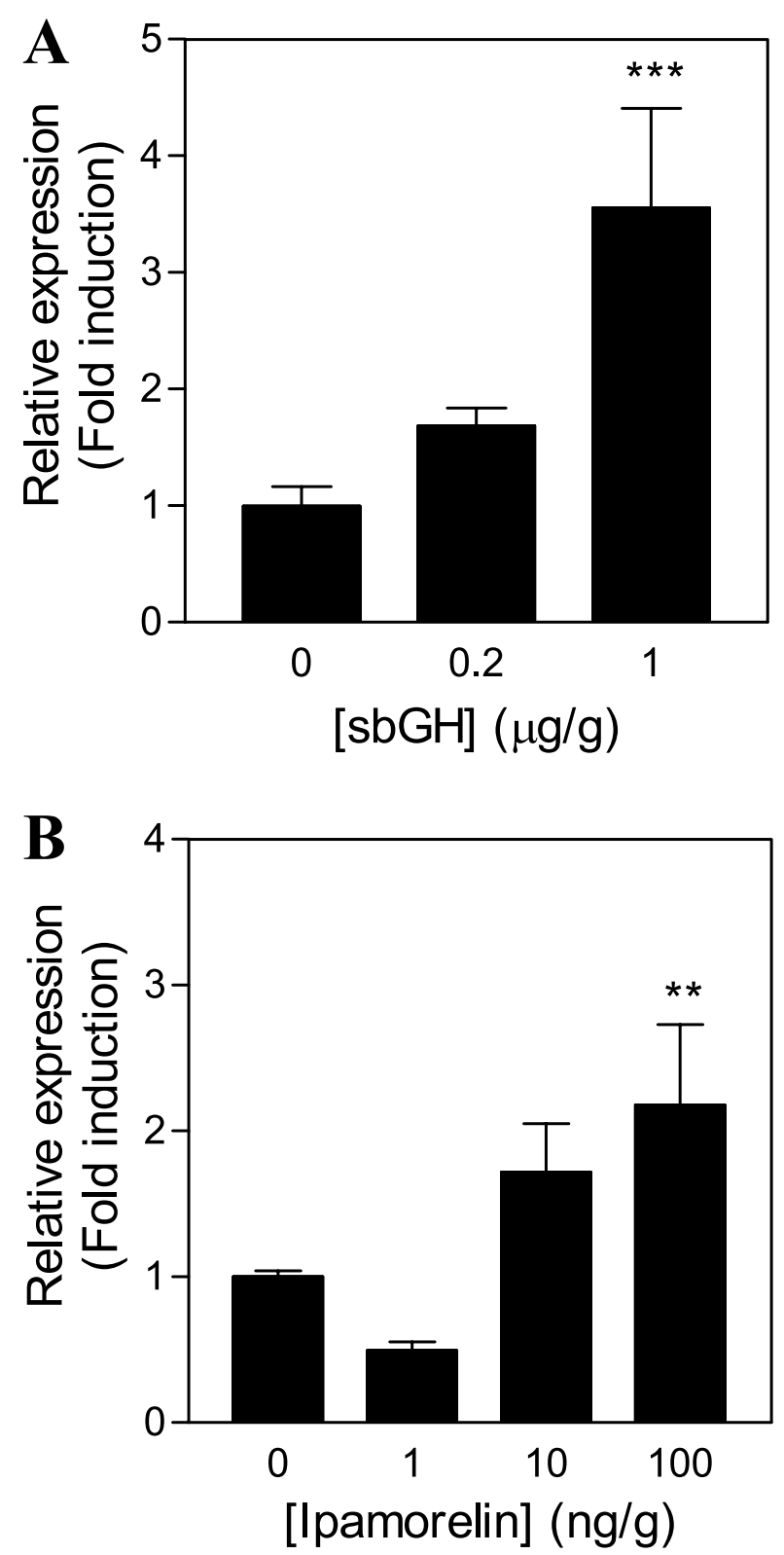

Figure 8 Seabream $\mathrm{GH}(\mathrm{sbGH} ; \mathrm{A})$ and ipamorelin (B) upregulates seabream ghrelin expression in stomach. Hormones of different concentrations were administered intraperitoneally into the fish as described in the Materials and Methods section. The expression level of ghrelin in different treatment groups were normalized by their corresponding $\beta$-actin expression and were expressed as means \pm S.E.M. $(n=6) .{ }^{* *} P<0 \cdot 01 ;{ }^{* *} P<0 \cdot 001$.

2001, Ikemoto \& Park 2003), indicating that seabream is more closely related to tilapia than to rainbow trout, and that goldfish is more distantly related to these fish species (Fig. 3). The structural organization of the seabream ghrelin gene (Fig. 4) is also similar to that of tilapia (Parhar et al. 2003). The sizes of the cloned seabream and tilapia 
ghrelin genes are 1771 and $1416 \mathrm{bp}$, respectively. Both genes are consisted of four exons and three introns. This pattern is in fact similar to that of goldfish, in which the genome size is only $980 \mathrm{bp}$ (Unniappan et al. 2002). However, the genomic organization in rainbow trout (Kaiya et al. 2003a) is different from that in other known fish species. It is consisted of five exons and four introns, which is more similar to that of the mouse ghrelin gene (Tanaka et al. 2001).

It is interesting to note that gene duplication has been observed for some components of the somatotropic axis in certain teleosts. For example, it has been reported that tilapia has two GH genes (Ber \& Daniel 1993). Cardoso et al. (2003) also suggested the presence of two GHreleasing hormone receptor genes in the Fugu rubripes genome. Furthermore, we have recently reported the identification of two GH receptors from the black seabream (Jiao et al. 2006). From the present study however, there is no evidence for the existence of multiple ghrelin genes in seabream. Whether ghrelin gene duplication occurred during teleost evolution awaits further investigation. In this context though, it is interesting to note that we have previously shown that there exists only a single gene for GHSR in the seabream genome (Chan \& Cheng 2004).

Although the ghrelin genes have been previously identified from a number of fish species, little is known about their promoter structures and functions. The transcriptional regulation of the teleostean ghrelin genes therefore remains poorly understood. To date, the 5'-flanking regions of the ghrelin genes from human and rat only have been isolated and characterized (Kishimoto et al. 2003, Kanamoto et al. 2004, Wei et al. 2005). Hence in the present study we have isolated a 2230-bp 5'-flanking region of the seabream ghrelin gene (Fig. 5) as a first step towards understanding its transcriptional regulation. Our results revealed that, similar to the human situation (Kishimoto et al. 2003), there is neither a GC box nor a CAAT box present in the isolated $5^{\prime}$-flanking region. A putative transcription start site is located at position -56 (Fig. 5), corresponding to the most $5^{\prime}$-end of the ghrelin transcripts (Fig. 1) identified from the seabream stomach cDNA library. Although a TATATAA element was found in the human ghrelin gene, deletion and mutation studies have shown that it is not important for promoter activity (Kishimoto et al. 2003). However, the seabream ghrelin gene does not contain any TATA-like element upstream of the putative transcription start site (Fig. 5). These observations therefore suggest that both mammalian and fish ghrelin genes are TATA-less. Incidentally this is the same as in the GHSR genes (Kaji et al. 1998, Petersenn et al. 2001, Tanaka et al. 2003, Yeung et al. 2004). However, the $5^{\prime}$-flanking region of the seabream ghrelin gene is found to contain a number of putative transcription factor-binding sites (Fig. 5) different from the human counterpart (Kishimoto et al. 2003), indicating that they are probably regulated in different manners. The functional analysis of the seabream ghrelin promoter gave further support to this notion since its cell-type specificity is different from that of human. The human ghrelin promoter was active in ECC10 cells (Kishimoto et al. 2003) but the seabream ghrelin promoter was totally inactive in this cell type. Instead, the seabream promoter exhibited strong activity in human colon epithelial adenocacinoma Caco-2 cells (Fig. 6). Limited by the unavailability of intestine-derived cell line from teleost species, it is not known whether the seabream promoter is also active in the same tissue type in fish. Nevertheless, no promoter activity was recorded in the fish cell line GAKS derived from scale epthelial cells.

Another difference between fish and human ghrelin genes is that there is only one transcription start site identified in seabream that is different from the situation in human where two transcription start sites were found (Kanamoto et al. 2004, Wei et al. 2005). Moreover, studies have suggested that E-box elements are involved in the promoter activation of the human ghrelin gene (Kanamoto et al. 2004) but no E-box elements were found in the seabream ghrelin promoter. Although ghrelin expression in both human and rat could be modulated by upstream stimulatory factor and glucagon stimulation, the regulation of ghrelin expression varied significantly between human and rat even though a $65 \%$ sequence identity was found between the core promoter regions of the human and rat ghrelin genes (Wei et al. 2005). These observations further suggest that the regulatory mechanisms of ghrelin expression are very different among species. Further studies on the transcriptional control of ghrelin expression in fish are highly warranted.

The expression of ghrelin and its receptor (GHSR) have been demonstrated in a number of human cells and tissues including immune cells, thyroid gland, pancreas, spleen, myocardium, adrenal gland, and ovary (Hattori et al. 2001, Gnanapavan et al. 2002, Volante et al. 2002, Gaytan et al. 2003). Their expression is also found in the mouse kidney (Mori et al. 2000) and embryo (Kawamura et al. 2003), and rat testis (Tena-Sempere et al. 2002, Barreiro et al. 2003) and adrenal (Barreiro et al. 2002, Andreis et al. 2003). These findings indicate that ghrelin is widely expressed and may play important physiological roles in different mammalian tissues. However, a recent study has shown that ghrelin is not critically required for the viability, fertility, growth, appetite, bone density, and fat deposition in a ghrelin-null mouse model (Sun et al. 2003). In spite of the diverse physiological functions that have been proposed for ghrelin in mammals, the ghrelin-null mice are visibly healthy and could reproduce normally (Sun et al. 2003). This study suggested that compensatory mechanisms probably accommodate some of the actions of ghrelin in the mutant mice. By analyzing ghrelin-deficient mice, another study (Wortley et al. 2004) has also indicated that endogenous ghrelin is not an essential regulator of food intake. However, it has been 
demonstrated that ghrelin plays a prominent role in determining the type of metabolic substrate employed for maintenance of energy balance (Wortley et al. 2004). More recently, another hormone called obestatin was found to be encoded by the ghrelin gene (Zhang et al. 2005). Obestatin appears to act as an anorexic hormone by decreasing food intake via activation of an orphan G-protein-coupled receptor GPR39. It has therefore been suggested that the reason why mutant mice with a deletion of the ghrelin gene do not exhibit impaired appetite or growth is that these animals lack both the orexigenic ghrelin and the anorexic obestatin (Zhang et al. 2005). Although no report has been published so far on the identification of teleostean obestatin, our sequence alignment shown in Fig. 2 indicates a putative region of low similarity to mammalian obestatin in the teleostean ghrelin prepropeptide, suggesting that an orthologue of mammalian obestatin might be present in fish. Further studies to substantiate this possibility are highly warranted. Previous studies have indicated that the function of ghrelin in stimulating $\mathrm{GH}$ release from the pituitary appears to be conserved from fish to mammals (Kaiya et al. 2003b, 2003c, Parhar et al. 2003). In particular, ghrelin has been shown to be capable of stimulating food intake in goldfish (Unniappan et al. 2002). The expression of ghrelin mRNA has also been demonstrated in the kidney and gill of some fish species (Kaiya et al. 2003b, 2003c), suggesting that it may have an autocrine or paracrine function in these organs. In the present study, ghrelin was found to be expressed significantly in the seabream stomach (Fig. 7). This result is similar to the findings in Nile tilapia (Parhar et al. 2003), rainbow trout (Kaiya et al. 2003a), eel (Kaiya et al. 2003b), Mozambique tilapia (Kaiya et al. 2003c) and catfish (Kaiya et al. 2005), but somewhat different from that in goldfish (Unniappan et al. 2002, Unniappan \& Peter 2005). Similar to the situation in Nile tilapia (Parhar et al. 2003), we did not detect ghrelin expression in all the other tissues examined. This might be due to a low expression level beyond the detection limit of RT-PCR. Actually, in eel and Mozambique tilapia, the authors could only detect ghrelin expression in the brain and gill of Mozambique tilapia and in other tissues of the eel using an extended number of PCR cycles. When a more sensitive method of real-time PCR was used, ghrelin expression could be detected in various tissues at very low levels in catfish (Kaiya et al. 2005). Further investigations on the expression of ghrelin using a more sensitive and quantitative method would be warranted to study the tissue-specific and developmental pattern of expression in seabream. In light of our previous finding that the seabream GHSR is mainly expressed in the central nervous system but not in the peripheral tissues (Chan \& Cheng 2004), it is envisaged that ghrelin secreted from the seabream stomach might have to traverse the blood-brain barrier to exert its physiological actions on the brain.
It has been demonstrated that ghrelin expression in the mammalian stomach is regulated by nutritional and energy status (Kim et al. 2003, Hanada et al. 2004, Sanchez et al. 2004). Moreover, it was found that the ghrelin expression in the rodent stomach was upregulated by estradiol, leptin and insulin (Toshinai et al. 2001, Matsubara et al. 2004), and downregulated in hyperthyroidism (Caminos et al. 2002). In fish, ghrelin expression was reported to be regulated by feeding conditions in which starvation increased ghrelin mRNA content in goldfish (Unniappan et al. 2004). This regulation of expression is sex-dependent in that an elevated ghrelin mRNA level could only be detected in the female cichlid fish (Parhar et al. 2003). However, information regarding its regulation of expression by other hormones is not available in any fish species. In the present study, we have demonstrated that ghrelin expression in the seabream stomach could be upregulated by both $\mathrm{GH}$ and the synthetic $\mathrm{GH}$ secretagogue ipamorelin (Fig. 8). This is indeed the first report on the homologous regulatory nature of this peptide in teleosts. While the physiological significance of this homologous upregulation in fish is not understood at present, conflicting results have been reported in mammals. Qi et al. (2003) have reported that GH exerts a negative-feedback effect on stomach ghrelin production in rats. On the other hand, however, Nass et al. (2004) have provided evidence that chronic changes in peripheral GH levels do not affect ghrelin stomach mRNA expression in mice.

Taking into consideration that ipamorelin is a potent $\mathrm{GH}$ secretagogue of $\mathrm{GH}$ secretion in seabream (Chan et al. $2004 a$ ) and that injection of $\mathrm{GH}$ in vivo could also upregulate ghrelin expression in the seabream stomach, it is possible that this homologous upregulation is $\mathrm{GH}$ mediated. However, the other possibility that ipamorelin exerts a direct action in stimulating ghrelin expression in stomach could not be excluded since both ghrelin and GHSR could be detected in the seabream stomach (Chan \& Cheng 2004). Further studies are needed to dissect the exact role of ipamorelin and GH in controlling the expression of ghrelin in the fish stomach. Interestingly, we have previously reported that the seabream GHSR promoter could be enhanced by another $\mathrm{GH}$ secretagogue (Yeung et al. 2004), indicating that this homologous upregulation mechanism is applicable to both the ligand and the receptor of the ghrelin/GHSR system in seabream.

In summary, we have isolated the cDNA and gene for ghrelin in a fish species in which its cognate receptor has been identified. Moreover, we also isolated and characterized the first ghrelin gene promoter in teleost. Similar to its receptor, the expression of seabream ghrelin could be enhanced by a GH secretagogue analogue. The identification of both the GHSR and ghrelin genes from seabream would facilitate our subsequent studies on the physiological functions and regulation of the fish ghrelin/GHSR system. 


\section{Acknowledgements}

The work described in the paper was supported by a grant from the Research Grant Council of the Hong Kong Special Administrative Region (project no. CUHK4149/ $01 \mathrm{M})$. We are grateful to The Chinese University of Hong Kong for the provision of direct grants and for the award of a postdoctoral fellowship (to $\mathrm{C}-\mathrm{M} \mathrm{Y}$ ). The authors declare that there is no conflict of interest that would prejudice the impartiality of this scientific work.

\section{References}

Andreis PG, Malendowicz LK, Trejter M, Neri G, Spinazzi R, Rossi GP \& Nussdorfer GG 2003 Ghrelin and growth hormone secretagogue receptor are expressed in the rat adrenal cortex: evidence that ghrelin stimulates the growth, but not the secretory activity of adrenal cells. FEBS Letters 536 173-179.

Barreiro ML, Pinilla L, Aguilar E \& Tena-Sempere M 2002 Expression and homologous regulation of GH secretagogue receptor mRNA in rat adrenal gland. European Journal of Endocrinology 147 677-688.

Barreiro ML, Suominen JS, Gaytan F, Pinilla L, Chopin LK, Casanueva FF, Dieguez C, Aguilar E, Toppari J \& Tena-Sempere M 2003 Developmental, stage-specific, and hormonally regulated expression of growth hormone secretagogue receptor messenger RNA in rat testis. Biology of Reproduction 68 1631-1640.

Ber R \& Daniel V 1993 Sequence analysis suggests a recent duplication of the growth hormone-encoding gene in Tilapia nilotica. Gene 125 143-150.

Caminos JE, Seoane LM, Tovar SA, Casanueva FF \& Dieguez C 2002 Influence of thyroid status and growth hormone deficiency on ghrelin. European Journal of Endocrinology 147 159-163.

Cardoso JC, Power DM, Elgar G \& Clark MS 2003 Genomic characterization of putative growth hormone releasing hormone (GHRH) receptor genes in the teleost fish Fugu rubripes. DNA Sequence 14 129-133.

Chabot B 1996 Directing alternative splicing: cast and scenarios. Trends in Genetics 12 472-478.

Chan CB \& Cheng CHK 2004 Identification and functional characterization of two alternatively spliced growth hormone secretagogue receptor transcripts from the pituitary of black seabream Acanthopagrus schlegeli. Molecular and Cellular Endocrinology 214 81-95.

Chan CB, Fung CK, Fung W, Tse MCL \& Cheng CHK 2004a Stimulation of growth hormone secretion from seabream pituitary cells in primary culture by growth hormone secretagogues is independent of growth hormone transcription. Comparative Biochemistry and Physiology C Toxicology \& Pharmacology 139 77-85.

Chan CB, Leung PK, Wise H \& Cheng CHK $2004 b$ Signal transduction mechanism of the seabream growth hormone secretagogue receptor. FEBS Letters 577 147-153.

Gaytan F, Barreiro ML, Chopin LK, Herington AC, Morales C, Pinilla L, Casanueva FF, Aguilar E, Dieguez C \& Tena-Sempere M 2003 Immunolocalization of ghrelin and its functional receptor, the type 1 a growth hormone secretagogue receptor, in the cyclic human ovary. Journal of Clinical Endocrinology and Metabolism 88 879-887.

Gnanapavan S, Kola B, Bustin SA, Morris DG, McGee P, Fairclough P, Bhattacharya S, Carpenter R, Grossman AB \& Korbonits M 2002 The tissue distribution of the mRNA of ghrelin and subtypes of its receptor, GHS-R, in humans. Journal of Clinical Endocrinology and Metabolism 87 2988-2991.
Gualillo O, Lago F, Gómez-Reino J, Casanueva FF \& Dieguez C 2003 Ghrelin, a widespread hormone: insights into molecular and cellular regulation of its expression and mechanism of action. FEBS Letters $\mathbf{5 5 2}$ 105-109.

Hanada T, Toshinai K, Date Y, Kajimura N, Tsukada T, Hayashi Y, Kangawa K \& Nakazato M 2004 Upregulation of ghrelin expression in cachectic nude mice bearing human melanoma cells. Metabolism 53 84-88.

Hattori N, Saito T, Yagyu T, Jiang BH, Kitagawa K \& Inagaki C $2001 \mathrm{GH}, \mathrm{GH}$ receptor, GH secretagogue receptor, and ghrelin expression in human T cells, B cells, and neutrophils. Journal of Clinical Endocrinology and Metabolism 86 4284-4291.

Ikemoto T \& Park MK 2003 Identification and characterization of the reptilian GnRH-II gene in the leopard gecko, Eublepharis macularius, and its evolutionary considerations. Gene 316 157-165.

Jiao B, Huang X, Chan CB, Zhang L, Wang D \& Cheng CHK 2006 The co-existence of two growth hormone receptors in teleosts and their differential signal transduction, tissue distribution and hormone regulation of expression in seabream. Journal of Molecular Endocrinology 36 23-40.

Kaiya H, Kojima M, Hosoda H, Koda A, Yamamoto K, Kitajima Y, Matsumoto M, Minamitake Y, Kikuyama S \& Kangawa K 2001 Bullfrog ghrelin is modified by n-octanoic acid at its third threonine residue. Journal of Biological Chemistry 276 40441-40448.

Kaiya H, Van Der Geyten S, Kojima M, Hosoda H, Kitajima Y, Matsumoto M, Geelissen S, Darras VM \& Kangawa K 2002 Chicken ghrelin: purification, cDNA cloning and biological activity. Endocrinology 143 3454-3463.

Kaiya H, Kojima M, Hosoda H, Moriyama S, Takahashi A, Kawauchi H \& Kangawa K 2003a Peptide purification, cDNA and genomic DNA cloning, and functional characterization of ghrelin in rainbow trout. Endocrinology 144 5215-5226.

Kaiya H, Kojima M, Hosoda H, Riley LG, Hirano T, Grau EG \& Kangawa K 2003b Amidated fish ghrelin: purification, cDNA cloning in the Japanese eel and its biological activity. Journal of Endocrinology 176 415-423.

Kaiya H, Kojima M, Hosoda H, Riley LG, Hirano T, Grau EG \& Kangawa K 2003c Identification of tilapia ghrelin and its effects on growth hormone and prolactin release in the tilapia, Oreochromis mossambicus. Comparative Biochemistry and Physiology B Biochemistry E Molecular Biology 135 421-429.

Kaiya H, Small BC, Bilodeau AL, Shepherd BS, Kojima M, Hosoda H \& Kangawa K 2005 Purification, cDNA cloning, and characterization of ghrelin in channel catfish, Ictalurus punctatus. General and Comparative Endocrinology 143 201-210.

Kaji H, Tai S, Okimura Y, Iguchi G, Takahashi Y, Abe H \& Chihara K 1998 Cloning and characterization of the 5'-flanking region of the human growth hormone secretagogue receptor gene. Journal of Biological Chemistry 273 33885-33888.

Kanamoto N, Akamizu T, Tagami T, Hataya Y, Moriyama K, Takaya K, Hosoda H, Kojima M, Kangawa K \& Nakao K 2004 Genomic structure and characterization of the $5^{\prime}$-flanking region of the human ghrelin gene. Endocrinology 145 4144-4153.

Kawamura K, Sato N, Fukuda J, Kodama H, Kumagai J, Tanikawa H, Nakamura A, Honda Y, Sato T \& Tanaka T 2003 Ghrelin inhibits the development of mouse preimplantation embryos in vitro. Endocrinology 144 2623-2633.

Kim MS, Yoon CY, Park KH, Shin CS, Park KS, Kim SY, Cho BY \& Lee HK 2003 Changes in ghrelin and ghrelin receptor expression according to feeding status. Neuroreport 14 1317-1320.

Kishimoto M, Okimura Y, Nakata H, Kudo T, Iguchi G, Takahashi Y, Kaji H \& Chihara K 2003 Cloning and characterization of the 5 -flanking region of the human ghrelin gene. Biochemical and Biophysical Research Communications 305 186-192.

Kojima M, Hosoda H, Date Y, Nakazato M, Matsuo H \& Kangawa K 1999 Ghrelin is a growth-hormone-releasing acylated peptide from stomach. Nature 402 656-660. 
Matsubara M, Sakata I, Wada R, Yamazaki M, Inoue K \& Sakai T 2004. Estrogen modulates ghrelin expression in the female rat stomach. Peptides 25 289-297.

Mori K, Yoshimoto A, Takaya K, Hosoda K, Ariyasu H, Yahata K, Mukoyama M, Sugawara A, Hosoda H, Kojima M et al. 2000 Kidney produces a novel acylated peptide, ghrelin. FEBS Letters 486 213-216.

Nass R, Liu J, Hellmann P, Coschigano KT, Gaylinn B, Berryman DE, Kopchick JJ \& Thorner MO 2004 Chronic changes in peripheral growth hormone levels do not affect ghrelin stomach mRNA expression and serum ghrelin levels in three transgenic mouse models. Journal of Neuroendocrinology 16 669-675.

Nilsson S, Makela S, Treuter E, Tujague M, Thomsen J, Andersson G, Enmark E, Pettersson K, Warner M \& Gustafsson JA 2001 Mechanisms of estrogen action. Physiological Reviews 81 1535-1565.

Palyha OC, Feighner SD, Tan CP, McKee KK, Hreniuk DL, Gao YD, Schleim KD, Yang L, Morriello GJ, Nargund R et al. 2000 Ligand activation domain of human orphan growth hormone $(\mathrm{GH})$ secretagogue receptor (GHS-R) conserved from Pufferfish to humans. Molecular Endocrinology 14 160-169.

Parhar IS, Sato H \& Sakuma Y 2003 Ghrelin gene in cichlid fish is modulated by sex and development. Biochemical and Biophysical Research Communications 305 169-175.

Petersenn S, Rasch AC, Penshorn M, Beil FU \& Schulte HM 2001 Genomic structure and transcriptional regulation of the human growth hormone secretagogue receptor. Endocrinology 142 2649-2659.

Qi X, Reed J, Englander EW, Chandrashekar V, Bartke A \& Greeley GH Jr 2003 Evidence that growth hormone exerts a feedback effect on stomach ghrelin production and secretion. Experimental Biology and Medicine (Maywood) 228 1028-1032.

Sanchez J, Oliver P, Palou A \& Pico C 2004 The inhibition of gastric ghrelin production by food intake in rats is dependent on the type of macronutrient. Endocrinology 145 5049-5055.

Sun Y, Ahmed S \& Smith RG 2003 Deletion of ghrelin impairs neither growth nor appetite. Molecular and Cellular Biology 23 7973-7981.

Tanaka M, Hayashida Y, Iguchi T, Nakao N, Nakai N \& Nakashima K 2001 Organization of the mouse ghrelin gene and promoter: occurrence of a short noncoding first exon. Endocrinology 142 3697-3700.

Tanaka M, Miyazaki T, Yamamoto I, Nakai N, Ohta Y, Tsushima N, Wakita M \& Shimada K 2003 Molecular characterization of chicken growth hormone secretagogue receptor gene. General and Comparative Endocrinology 134 198-202.

Tena-Sempere M, Barreiro ML, Gonzalez LC, Gaytan F, Zhang FP, Caminos JE, Pinilla L, Casanueva FF, Dieguez C \& Aguilar E 2002 Novel expression and functional role of ghrelin in rat testis. Endocrinology 143 717-725.
Toshinai K, Mondal MS, Nakazato M, Date Y, Murakami N, Kojima M, Kangawa K \& Matsukura S 2001 Upregulation of ghrelin expression in the stomach upon fasting, insulin-induced hypoglycemia, and leptin administration. Biochemical and Biophysical Research Communications 281 1220-1225.

Unniappan S \& Peter RE 2005 Structure, distribution and physiological functions of ghrelin in fish. Comparative Biochemistry and Physiology. A. Molecular E Integrative Physiology 140 396-408.

Unniappan S, Lin X, Cervini L, Rivier J, Kaiya H, Kangawa K \& Peter RE 2002 Goldfish ghrelin: molecular characterization of the complementary deoxyribonucleic acid, partial gene structure and evidence for its stimulatory role in food intake. Endocrinology 143 4143-4146.

Unniappan S, Canosa LF \& Peter RE 2004 Orexigenic actions of ghrelin in goldfish: feeding-induced changes in brain and gut mRNA expression and serum levels, and responses to central and peripheral injections. Neuroendocrinology 79 100-108.

Volante M, Allia E, Gugliotta P, Funaro A, Broglio F, Deghenghi R, Muccioli G, Ghigo E \& Papotti M 2002 Expression of ghrelin and of the GH secretagogue receptor by pancreatic islet cells and related endocrine tumors. Journal of Clinical Endocrinology and Metabolism 87 1300-1308.

Wei W, Wang G, Qi X, Englander EW \& Greeley GH Jr 2005 Characterization and regulation of the rat and human ghrelin promoters. Endocrinology 146 1611-1625.

Wortley KE, Anderson KD, Garcia K, Murray JD, Malinova L, Liu R, Moncrieffe M, Thabet K, Cox HJ, Yancopoulos GD et al. 2004 Genetic deletion of ghrelin does not decrease food intake but influences metabolic fuel preference. PNAS $1018227-8232$.

Yeung CM, Chan CB \& Cheng CHK 2004 Isolation and characterization of the $5^{\prime}$-flanking region of the growth hormone secretagogue receptor gene from black seabream Acanthopagrus schlegeli. Molecular and Cellular Endocrinology 223 5-15.

Zhang JV, Ren PG, Avsian-Kretchmer O, Luo CW, Rauch R, Klein C \& Hsueh AJW 2005 Obestatin, a peptide encoded by the ghrelin gene, opposes ghrelin's effects on food intake. Science 310 996-999.

Zhu Y, Yoshiura Y, Kikuchi K, Aida K \& Thomas P 1999 Cloning and phylogenetic relationship of red drum somatolactin cDNA and effects of light on pituitary somatolactin mRNA expression. General and Comparative Endocrinology 113 69-79.

Received in final form 17 December 2005

Accepted 2 February 2006

Made available online as an Accepted Preprint

2 February 2006 